\title{
Synthesis and Electrochemical Characterization of Graphene Nanoribbon stacks Functionalized with Buckyballs
}

\author{
Boštjan Genorio \\ University of Ljubljana, Faculty of Chemistry and Chemical Technology, Večna pot 113, 1000 Ljubljana, Slovenia \\ *Corresponding author: E-mail: bostjan.genorio@fkkt.uni-lj.si \\ Tel: +38641839686
}

Received: 15-04-2015

\begin{abstract}
Graphene nanoribbons were prepared from commercially-available multi-walled carbon nanotubes and in situ functionalized with $\mathrm{C}_{60}$ - buckyballs. The physical properties of the synthesized functionalized material were analyzed by scanning electron microscopy, transmission electron microscopy, evolved gas analysis and Raman spectroscopy, and were compared to non-functionalized material. Further, electrochemical characterization was done to evaluate the redox-activity and capacity of the material in Li-ion batteries. Comparison to non-functionalized material shows improved capacity at lower current densities.
\end{abstract}

Keywords Graphene nanoribbon stacks, buckyballs, $\mathrm{C}_{60}$, functionalization, electrochemistry, Li-ion battery

\section{Introduction}

Carbon-based materials are one of the main components of energy conversion and storage devices. Various carbon allotropes can be found as catalyst supports in fuel cells, active materials in capacitors, and active components or conductive additives in batteries. ${ }^{1}$ Recently, graphene and its sub-structure graphene nanoribbons (GNRs) - both two-dimensional allotropes of carbon - have attracted attention in the field of energy storage and conversion due to their advantageous properties such as: high conductivity, high surface area and mechanical stability. High quality - low defect graphene materials are envisioned to be a main component of future electronics, however low quality graphene materials on the other hand which still features high conductivity, high surface area, mechanical stability and facile processability are already paving their way to the commercialization. There are several reports on use of graphene in Li-ion batteries and supercapacitors, ${ }^{2-4}$ where the addition of graphene has been shown to significantly enhance battery cycling performance and lithium storage capacity. Graphene can also effectively relieve the expansion and shrinkage of active materials during cell operation. ${ }^{5}$ The majority of the battery literature discusses graphene as either an anode intercalation mate- rial, a volume expansion buffer, or an electron transfer medium (for both cathode and anode materials). ${ }^{6}$ There are also reports on dual-graphite cells where graphene stacks are used as both, the anode and cathode. ${ }^{7}$ Carbon materials are also well-known supercapacitor components for storing electrostatic charges on the electrode doublelayer; ${ }^{8-10}$. However, the use of graphene based materials as a redox-active component of a battery system is still underexplored.

Graphene is, by itself, redox-inactive, and as a result functionalization with redox-active molecules is required. One of the redox active candidates is $\mathrm{C}_{60}$-fullerene. $\mathrm{C}_{60}$ has a rich redox chemistry, where six electrons per molecule can be exchanged at potentials $\left(\mathrm{E}_{1 / 2}\right)$ : $-0.98,-1.37$, $-1.87,-2.35,-2.85$, and $-3.26 \mathrm{~V}$ vs ferrocene $\left(\mathrm{Fc} / \mathrm{Fc}^{+}\right){ }^{11}$ Functionalization can have a major impact on the conductivity of the material; therefore an edge functionalization is preffered. ${ }^{12}$ In order to achieve high degree of edge functionalization, high aspect ratio graphene analogues such as GNRs should be considered. Focusing on high aspect ratio GNRs, two general approaches can be applied: a) covalent functionalization, and b) non-covalent functionalization. ${ }^{13}$ Both approaches can be used in supercapacitor and $\mathrm{Li}$-ion battery electrode material synthesis. The redox-active material most commonly used in non-covalent 
functionalization approach is $\mathrm{MnO}_{2}$, which has been described in several reports. ${ }^{14,15}$ Using a covalent functionalization approach, our group has previously shown that quinone-based functional groups on GNRs can be used as an electrode material for Li-Ion batteries. ${ }^{16}$

In the present study, we explored the possibility of developing an all-carbon hybrid electrode material for Liion battery that is conductive and redox-active at the same time. In order to develop redox activity in an all-carbon material, we focused on functionalization with buckyball- $\mathrm{C}_{60}$ fullerenes. All-carbon, hybrid $\mathrm{C}_{60}$-GNR material was synthesized according to previously described, modified synthesis/functionalization method. ${ }^{12,17}$ Using commercialy available multi-walled carbon nanotube (MWCNT) starting materials, this in situ functionalization method yielded GNRs that are edge functionalized with $\mathrm{C}_{60}$. This material was characterized with scanning electron microscopy (SEM), transmission electron microscopy (TEM), evolved gas analysis (EGA), and Raman spectroscopy. Further, hybrid $\mathrm{C}_{60}$-GNR material was subjected to electrochemical characterization in a Li-ion battery setup using linear scan cyclic voltammetry $(\mathrm{CV})$ and galvanostatic measurements with different current rates.

\section{Results and Discussion}

Fullerene $\mathrm{C}_{60}$ is a well-known electrophile that can readily react with electron-rich systems. ${ }^{18}$ It has also been shown that electrophiles may functionalize graphene nanoribbons by displacing alkali metal sources on graphene nanoribbons. ${ }^{12.17} \mathrm{C}_{60}$ functionalized GNRs $\left(\mathbf{C}_{60}\right.$-GNRs $)$ were synthesized using a one-pot, in situ functionalization method with MWCNTs as starting material, $\mathrm{Na} / \mathrm{K}$ alloy and $\mathrm{C}_{60}$ as reagents and 1,2-dimethoxyethane (DME) as solvent (Scheme 1). In the last step, methanol was used to quench all of the residual activated carbon and excess $\mathrm{Na} / \mathrm{K}$ that remained after unzipping and/or $\mathrm{C}_{60}$ addition. To serve as a reference material, non-functionalized GNRs (GNRs) were also synthesized. In this case active carbon centers were quenched by methanol and no electrophile was used.

Synthesized $\mathbf{C}_{60}$-GNRs were imaged by scanning electron microscopy (SEM) and transmission electron microscopy (TEM) (Figure 1). SEM imaging (Figure 1a) revealed high yield splitting of MWCNTs to GNRs (additional large scale SEM images can be found in Supporting Information Figure S1). Furthermore, TEM imaging shows the presence of round structures on the edges of the $\mathbf{C}_{60}$-GNRs. These structures are $<2 \mathrm{~nm}$ in diameter, which is comparable to the van der Waals diameter of $\mathrm{C}_{60}$ molecules and suggests that $\mathrm{C}_{60}$ has been successfully covalently bound to the edge of the GNR (additional TEM images of $\mathrm{C}_{60}$-GNRs can be found in Supporting Information Figure S2). However, for a clearer confirmation of covalent functionalization, more detailed high resolution TEM studies should be conducted, as similar fullerenic structures have also been shown on raw samples of combustion-generated fullerenes. ${ }^{19}$ Regardless, according to Figure $1 \mathrm{~b}$ the degree of possible functionalization is relatively low (for TEM images of MWCNTs and GNRs see Supporting Information Figure S3). To further explore the degree of possible functionalization, the indirect evolved gas analysis (EGA) method was used.

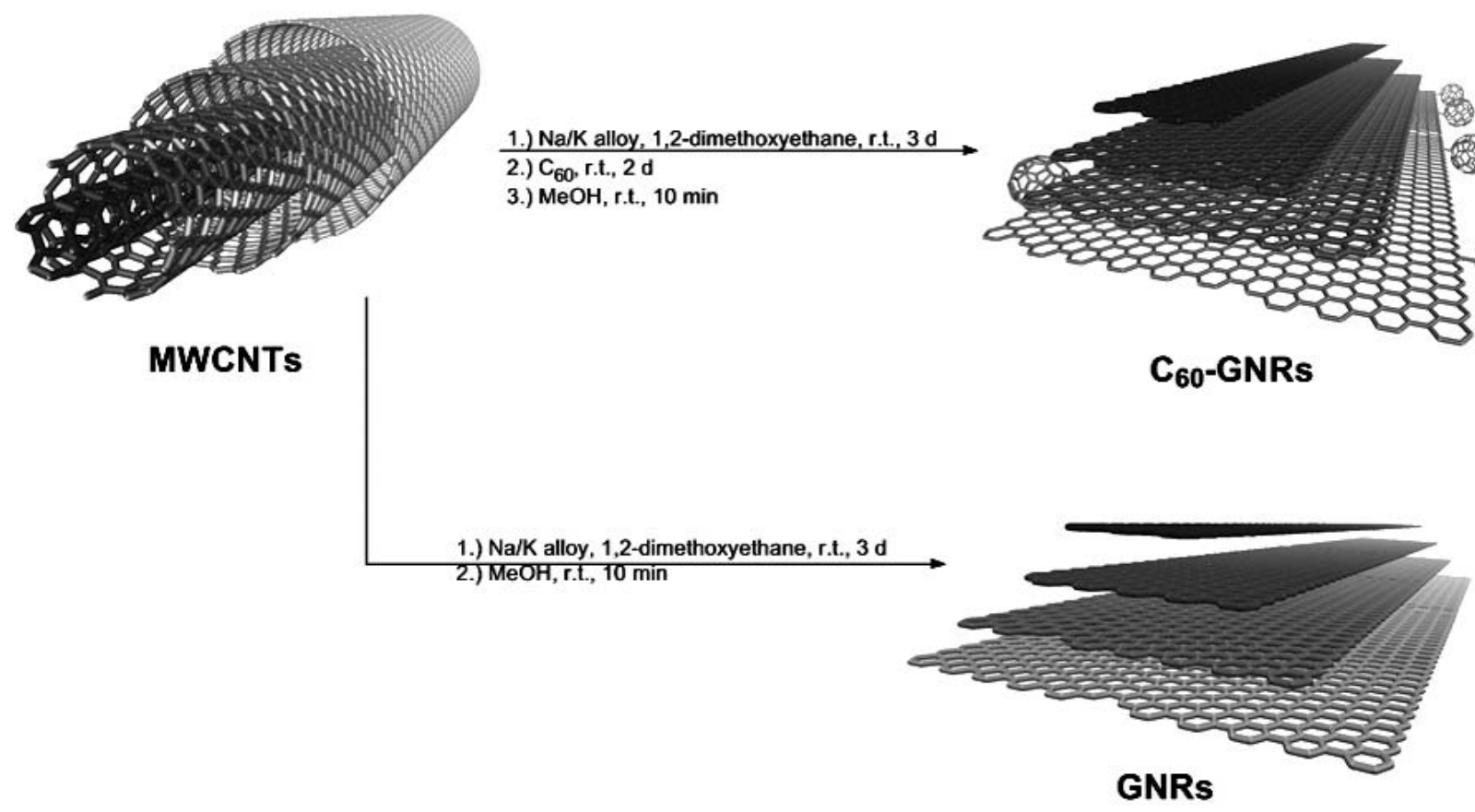

Scheme 1. Proposed reaction scheme for synthesis of $\mathrm{C}_{60}$-GNRs and GNRs. 
a)

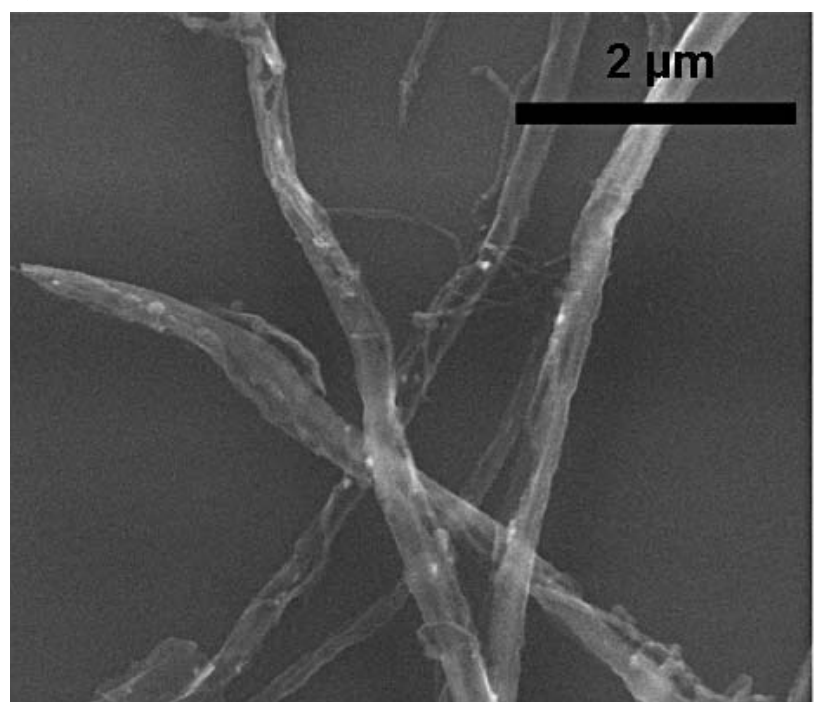

b)

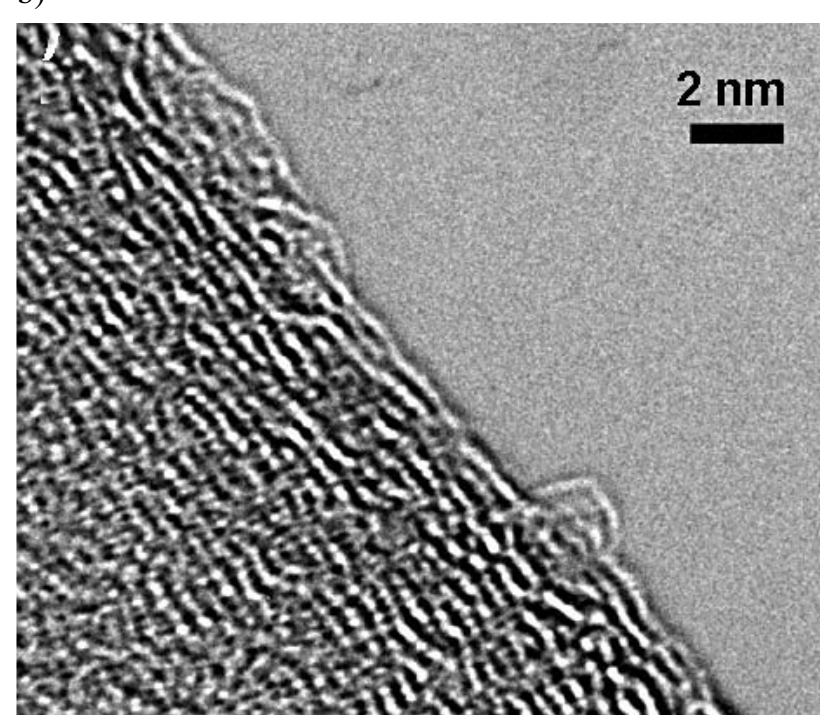

Figure 1. Images of synthesized $\mathbf{C}_{60}$-GNRs. a) SEM image, b) TEM image

Comparing the EGAs of $\mathbf{C}_{\mathbf{6 0}}{ }^{-}$GNRs and GNRs (Figure 2) one can see that the difference in total weight loss between two samples is $13.4 \%$ at $900{ }^{\circ} \mathrm{C}$. MS spectra revealed that main difference in weight loss is due to adsorbed water, which is slowly released from the materials in the range between $60{ }^{\circ} \mathrm{C}$ to $260{ }^{\circ} \mathrm{C}$ and observed to be higher for $\mathbf{C}_{\mathbf{6 0}}$-GNRs. However, the most important difference between the functionalized and non-functionalized materials is the presence of a mass fragment at $\mathrm{m} / \mathrm{z}=64$ (purple curve of Figure 2) in case of $\mathbf{C}_{60}$-GNRs. Fragmentation of $\mathrm{C}_{60}$ is a very complex process. It was previously shown that $\mathrm{C}_{60}$ decomposes to several fragments with $\mathrm{m} / \mathrm{z}$ $\mathrm{M}=\mathrm{C}_{60-2 \mathrm{n}}{ }^{\mathrm{m}+} \cdot{ }^{20}$ Extrapolating this formula one can assume that fragment $\mathrm{m} / \mathrm{z}=64$ could be $\mathrm{C}_{16}{ }^{3+}$. Further, another publication discusses plausible mechanisms for the thermal decomposition of $\mathrm{C}^{60} \cdot{ }^{21}$ They discuss possible formation of complexes with trace impurities such as oxygen, carbon, and hydrogen. Consequently, one could also expect that fragment $\mathrm{m} / \mathrm{z} 64$ could be $\mathrm{C}_{4} \mathrm{O}^{+}$or $\mathrm{C}_{5} \mathrm{H}_{4}^{+}$. However, in order to confirm the chemical structure of the species with fragment $\mathrm{m} / \mathrm{z} 64$ extensive studies should be carried out, which is beyond the scope of this manuscript. However, above mentioned indicates possible presence of $\mathrm{C}_{60}$ moieties in the composition of functionalized $\mathbf{C}_{60}{ }^{-}$GNRs. Due to the limitations of the technique and the apparatus (the upper limit of detection is $100 \mathrm{AMU}$ ), one cannot directly observe the molecular mass of $\mathrm{C}_{60}$ with $\mathrm{m} / \mathrm{z} 720\left(\mathrm{C}_{60}{ }^{+}\right)$or conclude whether the functionalization is covalent or non-covalent. We have shown previously that GNRs-based materials decompose with the appearance of fragment m/z 15 (blue curve of Figure 2) in the temperature region between $400{ }^{\circ} \mathrm{C}$ and $600{ }^{\circ} \mathrm{C} .{ }^{12}$ This fragment can be found in both spectra, which indicates that both materials decompose in the same fashion. To estimate degree of functionalization, calculation based on EGA data together with SEM images was applied (Supporting Information Table S4, Figure S5, Figure S6). Similar method was used in our previous publications. ${ }^{12,22}$ Following experimental data were used: a) defunctionalization of $\mathbf{C}_{60}$-GNRs is occurring in the temperature region between $380{ }^{\circ} \mathrm{C}$ and $600{ }^{\circ} \mathrm{C}$, b) average size of the ribbon was $30,000 \mathrm{~nm} \times 200 \mathrm{~nm}, \mathrm{c}$ ) weight loss related to $\mathrm{C}_{60}$ was

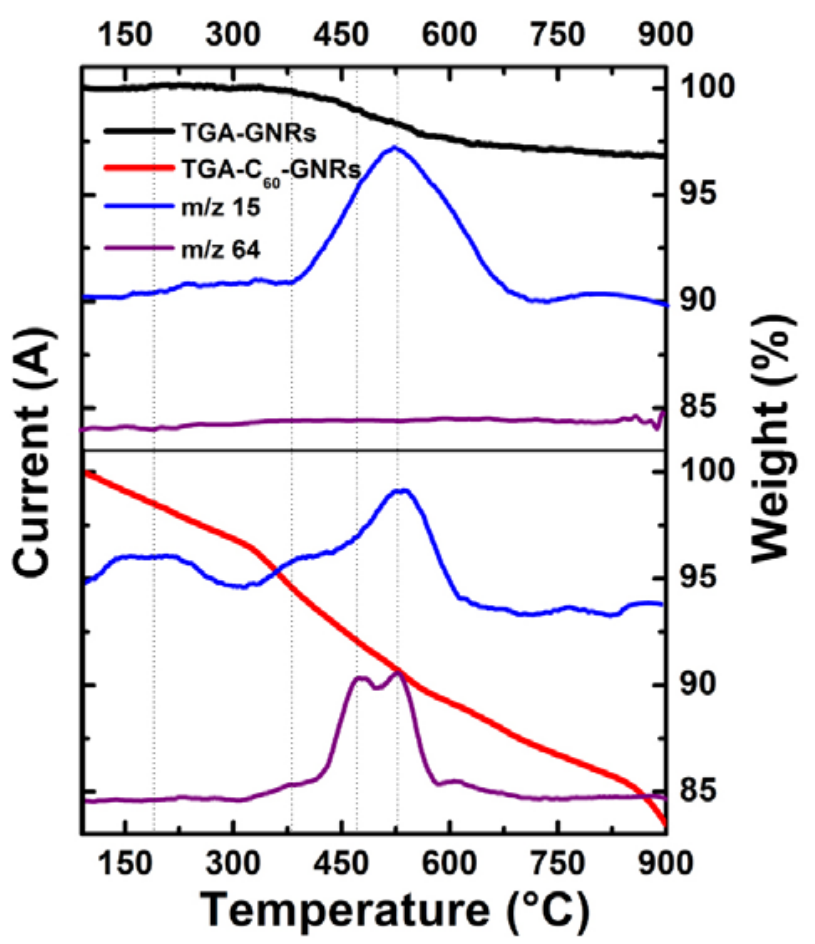

Figure 2. Evolved gas analysis. Black and red curves represent the TGA profile of GNRs and $\mathbf{C}_{60}$-GNRs respectively. Blue and purple lines represent fragments with $\mathrm{m} / \mathrm{z}$ fragments that correspond to $\mathrm{m} / \mathrm{z} 15$ and m/z 64, respectively. 
$3.2 \%$. Considering above mentioned the estimated degree of functionalization is 600 atomic ppm.

Raman spectroscopy of $\mathbf{C}_{60}$-GNRs was also performed to evaluate the structural quality of these materials. As shown in Figure 3, there is no noticeable difference between two spectra. They both show characteristic peaks for graphene-based materials: $\mathrm{D}$ at $\sim 1352 \mathrm{~cm}^{-1}, \mathrm{G}$ at $\sim 1583 \mathrm{~cm}^{-1}$, D' at $\sim 1635 \mathrm{~cm}^{-1}, 2 \mathrm{D}$ at $\sim 2708 \mathrm{~cm}^{-1}$, and $\mathrm{G}+\mathrm{D}^{\prime}$ at $\sim 2945 \mathrm{~cm}^{-1} .{ }^{23}$ The $\mathrm{I}_{\mathrm{D}} / \mathrm{I}_{\mathrm{G}}$ ratio was also estimated, which is an indicator of the structural disorder in graphitic materials. In both cases $\mathrm{I}_{\mathrm{D}} / \mathrm{I}_{\mathrm{G}}$ is relatively low - $0.6-$ which indicates that the GNRs are of relatively high quality and that the functionalization process does not disrupt the quality of the supporting GNR material. We have previously shown that materials with similar $\mathrm{I}_{\mathrm{D}} / \mathrm{I}_{\mathrm{G}}$ ratios show relatively good electronic conductivity, which is important for energy conversion and storage devices. ${ }^{12}$

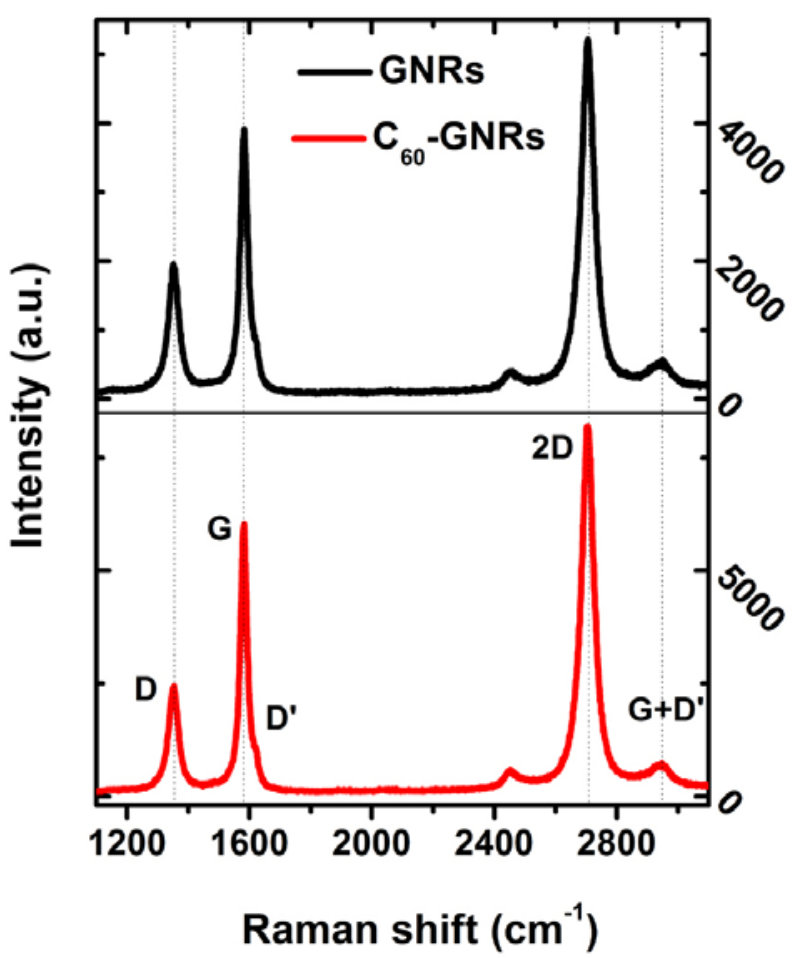

Figure 3. Raman spectra comparing non-functionalized (black curve) GNRs and functionalized (red curve) $\mathbf{C}_{60}$-GNRs.

For electrochemical measurements, the so-called "coffee bag" battery setup with $\mathbf{C}_{60}$-GNRs or GNRs as a working electrode and $\mathrm{Li}$ foil as a counter electrode was used. It is important to emphasize that working electrodes were prepared without any added binders or conductive additives, which is critical when considering practical applications for electrode materials. Cyclic voltammetry (CV) was measured for these materials (Figure 4), and from the 1st scan two oxidation peaks at $3.6 \mathrm{~V}$ and $3.9 \mathrm{~V}$ can be seen as shoulders in the red curve of Figure 4. The- se two peaks could represent oxidation of the $\mathrm{C}_{60}$ molecules present in the functionalized material $\mathbf{C}_{60}$-GNRs. However, instead of complementary, reversible reduction peaks in the reverse scan, only one broad reduction peak starting at $2.5 \mathrm{~V}$ is visible. This could indicate highly irreversible redox reaction of $\mathrm{C}_{60}$ moiety on GNRs. CV measurements also reveal that the oxidation and reduction currents slowly decrease with cycling. In contrast, non-functionalized GNRs show a much smaller, broad reduction peak and no oxidation peak (black curve of Figure 4). This indicates that $\mathrm{C}_{60}$ functionalization improves the electrochemical performance of GNR materials; however, the irreversibility of electrochemistry is a definite drawback for possible application in real Li-ion battery systems. Similar electrochemistry was also observed previously for the pure $\mathrm{C}_{60}$ which was used as a cathode in Liion battery setup. ${ }^{24}$ The electrochemical irreversibility of $\mathbf{C}_{60}$-GNRs material could also be the result of a reaction between oxidized species and the electrolyte or due to formation of a solid-electrolyte interphase on the electrode. Nevertheless, the functionalization showed improved electrochemistry when compared to non-functionalized material.

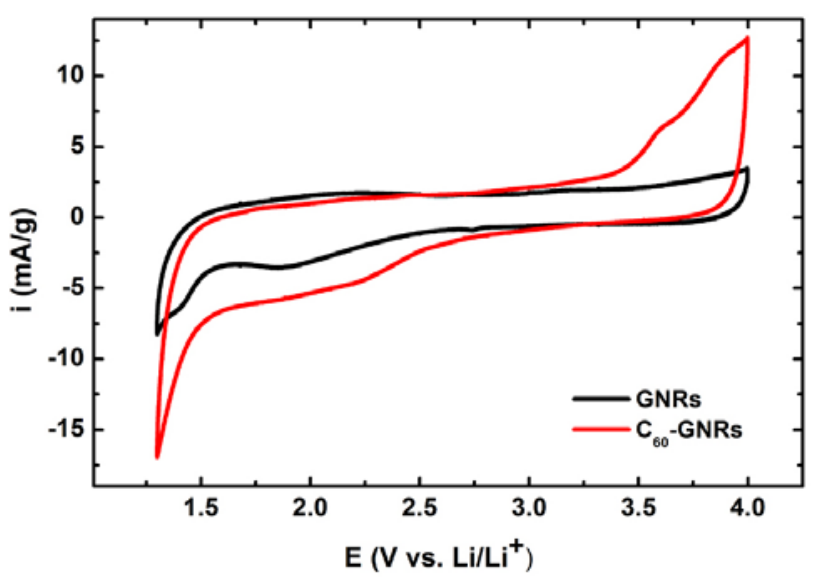

Figure 4. Cyclovoltammograms for non-functionalized GNRs (black curve) and functionalized $\mathbf{C}_{60}$-GNRs (red curve); scan rate $0.1 \mathrm{mV} / \mathrm{s}$.

Charge-discharge rate capability is one of the most important properties of cathode materials that can be used in lithium batteries. Galvanostatic rate capability tests for both of the materials: $\mathbf{C}_{60}{ }^{-}$GNRs and GNRs were performed (Figure 5), which show higher capacities for the functionalized $\mathbf{C}_{60}-\mathbf{G N R s}$ material. At low current densities the capacity for $\mathbf{C}_{60}-\mathbf{G N R s}(22 \mathrm{mAh} / \mathrm{g})$ is twice that of the non-functionalized GNRs (12 mAh/g) (for charge-discharge curves see Supporting Information Figures S7 and S8). However, at higher current densities $(800 \mathrm{~mA} / \mathrm{g})$ the capacity difference between two materials decreases until the capacities are equal $(6 \mathrm{mAh} / \mathrm{g})$. This means that rate performance for $\mathbf{C}_{60}-\mathbf{G N R s}$ is actually worse than for GNRs. 
As functionalization does not noticeably increase the surface area, one can expect that the difference in capacity for low current densities is related to activity of the functional groups. Furthermore, it is possible that the slow redox kinetics of $\mathrm{C}_{60}$ or lower the conductivity of the functionalized material relative to non-functionalized, leading to the poor rate capability. It is known from previous reports that conductivity can decrease with functionalization. ${ }^{1}$ Different contact resistance between single C60-GNRs can also impact fast capacity drop at higher current densities. We have shown previously, that alignment of the graphene nanoribbons drastically affect the contact resistance. ${ }^{17}$ In this respect, spherical $\mathrm{C}_{60}$ functionalities might disturb favorable alignment, increase contact resistance, and consequently cause fast capacity drop at higher current densities. However, the reason for the poor rate capability of these materials remains unclear at this point.

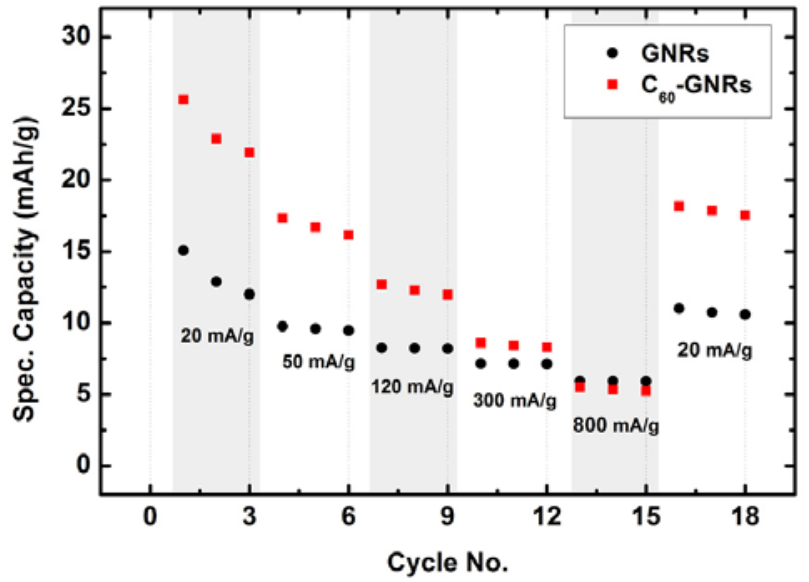

Figure 5. Rate capability for non-functionalized GNRs (black circles) and functionalized $\mathbf{C}_{60}$-GNRs (red squares) at $20 \mathrm{~mA} / \mathrm{g}$, $50 \mathrm{~mA} / \mathrm{g}, 120 \mathrm{~mA} / \mathrm{g}, 300 \mathrm{~mA} / \mathrm{g}$, and $800 \mathrm{~mA} / \mathrm{g}$ current densities.

\section{Conclusions}

Functionalization of GNRs with electroactive moieties is an approach that could lead to novel cathode materials for a variety of battery applications. In the present study, MWCNTs were split to GNRs in situ and functionalized with $\mathrm{C}_{60}$ fullerenes. These functionalized $\mathbf{C}_{60^{-}}$ GNR materials were compared to non-functionalized GNRs and characterized using a variety of imaging and electrochemical techniques. SEM imaging revealed high yield splitting of MWCNTs to GNRs and TEM imaging shows the presence of spherical structures on the GNR edges that suggest the presence of attached $\mathrm{C}_{60}$. Further, EGA analysis supports the hypothesis of successful functionalization of these structures with $\mathrm{C}_{60}$. In particular, it reveals that the mass fragment at $\mathrm{m} / \mathrm{z}=64$ is present only for the functionalized $\mathbf{C}_{60}{ }^{-}$GNRs material. As the fragment at $\mathrm{m} / \mathrm{z}=64$ is also one of the fragments observed for pure $\mathrm{C}_{60}$, it could be an indicator of the presence of $\mathrm{C}_{60}$ functional groups. These results favor the hypothesis of successful functionalization, however, at this time it cannot be confirmed conclusively whether $\mathrm{C}_{60}$ molecules are adsorbed or covalently bound. The graphitic nature of the functionalized material was confirmed by Raman spectroscopy, where bands typical for graphene are present. Further, a relatively small $\mathrm{I}_{\mathrm{D}} / \mathrm{I}_{\mathrm{G}}$ ratio is a good indicator of low concentration of structural defects in the graphene lattice, and confirms that the functionalization with $\mathrm{C}_{60}$ does not disrupt the quality of the GNR supporting material. Electrochemical experiments, in particular CV, showed irreversible redox reaction of functionalized material in first cycles. Galvanostatic cycling was performed under various current densities for both samples $-\mathbf{C}_{60}{ }^{-}$GNRs and GNRs and compared. Results showed doubled capacity for $\mathbf{C}_{60}$-GNRs on one hand, but worse rate performance on the other hand. Nevertheless, the improved capacity at low current densities for functionalized GNR materials, in combination with the simple assembly method of the electrode where no binders or conductive additives are used, make these materials attractive for further investigation. These materials may also be attractive for beyond lithium systems, e.g. Mg-ion batteries, where reversible cycling of $\mathrm{Mg}$ with pure $\mathrm{C}_{60}$ was shown recently. ${ }^{25}$

\section{Experimental}

\section{1. Materials}

All reactions were performed in dried glassware under an Ar atmosphere unless stated otherwise. Reagent grade 1,2-dimethoxyethane was degassed with Ar, refluxed over $\mathrm{Na} / \mathrm{K}$ alloy in an $\mathrm{Ar}$ atmosphere and freshly distilled. Other solvents were used without further distillation. NTL - M grade MWCNTs were donated by Nanotech Labs, Inc. (5T10M10). All other commercially available reagents were used as received. Liquid $\mathrm{Na} / \mathrm{K}$ alloy was prepared in a vial inside of a $\mathrm{N}_{2}$ glove box by pressing together freshly cut $\mathrm{K}$ ( 1 molar equivalent) and $\mathrm{Na}(0.22$ molar equivalents) chunks using tweezers to facilitate the melting process. Amounts of liquid Na/K alloy indicated are by volume. Caution: All synthetic steps involving $\mathrm{Na} / \mathrm{K}$ alloy should be carried out with extreme caution under strict exclusion of air or moisture, under inert gas and appropriate personal protection (hood, blast shields, face shield, protective and fire resistant clothing) should be used and worn at all times. $\mathrm{C}_{60}$ was obtained from Sigma-Aldrich and used as received without further purification. Milli-Q water was used during purification of the products.

\section{2. Synthesis of $\mathrm{C}_{60}$ Functionalized Graphene Nanoribbons Stacks $\left(\mathrm{C}_{60}{ }^{-} \mathrm{GNRs}\right)$}

To an vacuum oven-dried $\left(200{ }^{\circ} \mathrm{C}\right) 250 \mathrm{~mL}$ roundbottom flask containing a magnetic stir bar were added the MWCNTs (100 mg, $8.3 \mathrm{mmol}$ ). The vessel was then 
transferred to a Ar glove box where freshly distilled 1,2dimethoxyethane $(43 \mathrm{~mL})$ and liquid $\mathrm{Na} / \mathrm{K}$ alloy $(0.1 \mathrm{~mL})$ were added. The flask containing the suspension was then sealed with a septum and was vigorously stirred (450 $\mathrm{RPM}$ ) at room temperature in glove-box for $3 \mathrm{~d}$. The reaction suspension was then quenched by the addition of the $\mathrm{C}_{60}(180 \mathrm{mg}, 0.25 \mathrm{mmol})$ and left to stir at the room temperature for an additional day. Reaction mixture was then transferred out of the glove-box where methanol $(20 \mathrm{~mL}$, $500 \mathrm{mmol}$ ) was added to quench any excess $\mathrm{Na} / \mathrm{K}$ alloy and the mixture was stirred at room temperature for 10 min. For workup, the reaction mixture was filtered over a $0.2 \mu \mathrm{m}$ pore size PTFE membrane. The filter cake was successively washed with THF $(100 \mathrm{~mL})$ and $\mathrm{CS}_{2}(100 \mathrm{~m}-$ $\mathrm{L})$ and exposed to Soxhlet extraction for $8 \mathrm{~h}$ to remove the unreacted $\mathrm{C}_{60}$. After extraction solid was dispersed in $\mathrm{CS}_{2}$ $(50 \mathrm{~mL})$ and sonicated for $1 \mathrm{~h}$. Solution was then filtrated again using PTFE 0,2 $\mu \mathrm{m}$ filter pad. The filter cake was successively washed with THF $(100 \mathrm{~mL}), i-\mathrm{PrOH}(100 \mathrm{~m}-$ $\mathrm{L}), \mathrm{H}_{2} \mathrm{O}(100 \mathrm{~mL}), i$-PrOH $(50 \mathrm{~mL}), \mathrm{THF}(50 \mathrm{~mL}), \mathrm{Et}_{2} \mathrm{O}$ $(50 \mathrm{~mL})$ and dried under high vacuum. Mass of the dried product was $80.6 \mathrm{mg}$.

\section{3. Synthesis of Non-functionalized Graphene Nanoribbons Stacks (GNRs)}

The same procedure as described above for synthesis of $\mathbf{C}_{\mathbf{6 0}}$-GNRs was followed, except that step where $\mathrm{C}_{60}$ was added was omitted.

\section{4. Electron Microscopy}

Samples were dispersed in chlorobenzene and bath sonicated using an ultrasonic cleaner for $15 \mathrm{~min}$ for a quick dispersion. A drop was cast on a $100 \mathrm{~nm} \mathrm{SiO} / \mathrm{Si}$ substrate and large area low resolution images were taken at $20 \mathrm{kV}$ under FEI Quanta 400 ESEM FEG scanning electron microscope. For more refined images of the synthesized structure at higher resolution, a JEOL 2010 transmission electron microscope was used with the sample drop cast on a coated TEM grid.

\section{5. Evolved Gas Analysis (EGA)}

Thermogravimetric measurements were performed on a Netzsch 449 F3 Jupiter ${ }^{\circledR}$ instrument under a dynamic Ar (5.0) flow with a flow rate of $60 \mathrm{~mL} / \mathrm{min}$ in a temperature range from $25{ }^{\circ} \mathrm{C}$ to $900{ }^{\circ} \mathrm{C}$. A heating rate of 10 $\mathrm{K} / \mathrm{min}$ was used. About $5 \mathrm{mg}$ of sample was placed in alumina $\left(\mathrm{Al}_{2} \mathrm{O}_{3}\right)$ crucible. Simultaneously mass spectrometry was performed on MS 403C Aëolos ${ }^{\circledR}$ with detector SEM Chenneltron and system pressure of $2 \times 10^{-5} \mathrm{mbar}$. Gasses evolved under TG heat treatment were transferred to mass spectrometer through transfer capillary: quartz ID $75 \mu \mathrm{m}$ which was heated up to $220{ }^{\circ} \mathrm{C}$. The upper limit of the mass spectrometer detector was 100 AMU.

\section{6. Raman Spectroscopy}

The Raman spectra were acquired using a Renishaw Raman RE01 microscope with $40 \times$ lens; $514 \mathrm{~nm}$ wavelength LASER was used for excitation.

\section{7. Electrochemical Tests}

$\mathbf{C}_{60}$-GNRs and GNRs ( $\left.\sim 5 \mathrm{mg}\right)$ were suspended in THF $(15 \mathrm{~mL})$ in an ultrasonic bath for 10 min until the suspension was homogeneous. The suspension was then filtered through a glassy fiber Whatman GF/A (battery separator) in a Millipore membrane filtration system. The diameter of the filtration disc was $25 \mathrm{~mm}$. The filtration resulted in a uniformly distributed material on a glassy fiber separator, from which $12 \mathrm{~mm}$ diameter discs were cut out. These discs were then transferred to an Ar glove-box and allowed to dry for 1 day. Modified Swagelok battery cells were assembled in the glove box (water and oxygen levels $<1 \mathrm{ppm}$ ). For every cell, 5 drops of $1 \mathrm{M} \mathrm{LiPF}_{6}$ in ethylene carbonate/diethyl carbonate $(\mathrm{EC} / \mathrm{DEC})=1: 1$ (vol.), purchased from Merck (LP40), were used. A lithium foil (Aldrich, $0.75 \mathrm{~mm}$ thick) as counter electrode was rolled and cut prior to assembly.

Electrochemical measurements were performed on a VMP3 potentiostat/galvanostat (Bio-Logic, France). Batteries were cycled be- tween 4.0 and $1.3 \mathrm{~V}$ versus metallic Li. CV measurements were performed in a two-electrode cell with a scan rate of $0.1 \mathrm{mV} / \mathrm{s}$. Galvanostatic cycling (rate capability) was performed at various current densities in a wide range from 20 to $800 \mathrm{~mA} / \mathrm{g}$.

\section{Acknowledgements}

I thank to Center of Excellence Low Carbon Technologies, Slovenia (CO NOT), Center of Excellence Advanced Materials and Technologies for the Future, Slovenia (CO NAMASTE) for financial support, Dr. Klemen Pirnat for electrochemical measurements and Dr. Barbara Novosel for EGA measurements. I also thank to Nanotech Labs, Inc. for the MWCNTs.

\section{References}

1. Rao, C.; Sood, A. Graphene: Synthesis, Properties, and Phenomena; Rao, C. N. R.; Sood, A. K., Eds.; 1st ed.; WileyVCH Verlag GmbH \& Co. KGaA: Weinheim, 2013.

2. Luo, B.; Liu, S.; Zhi, L. Small 2012, 8, 630-646. http://dx.doi.org/10.1002/smll.201101396

3. Zhang, L. L.; Zhou, R.; Zhao, X. S. J. Mater. Chem. 2010, 20, 5983-5992. http://dx.doi.org/10.1039/c000417k

4. Huang, Y.; Liang, J.; Chen, Y. Small 2012, 8, 1805-1834. http://dx.doi.org/10.1002/smll.201102635 
5. Liang, M.; Zhi, L. J. Mater. Chem. 2009, 19, 5871-5878. http://dx.doi.org/10.1039/b901551e

6. Raccichini, R.; Varzi, A.; Passerini, S.; Scrosati, B. Nat. Mater. 2014, 14, 271-279. http://dx.doi.org/10.1038/nmat4170

7. Placke, T.; Fromm, O.; Lux, S. F.; Bieker, P.; Rothermel, S.; Meyer, H.-W.; Passerini, S.; Winter, M. J. Electrochem. Soc. 2012, 159, A1755-A1765. http://dx.doi.org/10.1149/2.011211jes

8. Zhu, Y.; Li, L.; Zhang, C.; Casillas, G.; Sun, Z.; Yan, Z.; Ruan, G.; Peng, Z.; Raji, A.-R. O.; Kittrell, C.; Hauge, R. H.; Tour, J. M. Nat. Commun. 2012, 3, 1225. http://dx.doi.org/10.1038/ncomms2234

9. Kotal, M.; Bhowmick, A. K. J. Phys. Chem. C 2013, 117, 25865-25875. http://dx.doi.org/10.1021/jp4097265

10. Zhang, C.; Peng, Z.; Lin, J.; Zhu, Y.; Ruan, G.; Hwang, C.C.; Lu, W.; Hauge, R. H.; Tour, J. M. ACS Nano 2013, 7, 5151-5159. http://dx.doi.org/10.1021/nn400750n

11. Echegoyen, L.; Echegoyen, L. E. Acc. Chem. Res. 1998, 31, 593-601. http://dx.doi.org/10.1021/ar970138v

12. Genorio, B.; Lu, W.; Dimiev, A. M.; Zhu, Y.; Raji, A.-R. O.; Novosel, B.; Alemany, L. B.; Tour, J. M. ACS Nano 2012, 6, 4231-4240. http://dx.doi.org/10.1021/nn300757t

13. Genorio, B.; Znidarsic, A. J. Phys. D. Appl. Phys. 2014, 47, 094012. http://dx.doi.org/10.1088/0022-3727/47/9/094012

14. Li, L.; Raji, A. R. O.; Tour, J. M. Adv. Mater. 2013, 25, 6298-6302. http://dx.doi.org/10.1002/adma.201302915

15. Liu, M.; Tjiu, W. W.; Pan, J.; Zhang, C.; Gao, W.; Liu, T. Nanoscale 2014, 6, 4233-4242.

http://dx.doi.org/10.1039/c3nr06650a
16. Pirnat, K.; Bitenc, J.; Jerman, I.; Dominko, R.; Genorio, B. ChemElectroChem 2014, 1, 2131-2137. http://dx.doi.org/10.1002/celc.201402234

17. Genorio, B.; Peng, Z.; Lu, W.; Hoelscher, B. K. P.; Novosel, B. J.; Tour, J. M. ACS Nano 2012, 6, 10396-10404. http://dx.doi.org/10.1021/nn304509c

18. Wudl, F. Acc. Chem. Res. 1992, 25, 157-161. http://dx.doi.org/10.1021/ar00015a009

19. Goel, A.; Howard, J. B.; Sande, J. B. V. Carbon N. Y. 2004, 42, 1907-1915. http://dx.doi.org/10.1016/j.carbon.2004.03.022

20. Baba, M. S.; Narasimhan, T. S. L.; Balasubramanian, R.; Mathews, C. K. J. Phys. Chem. 1995, 99, 3020-3032. http://dx.doi.org/10.1021/j100010a010

21. Sundar, C. S.; Bharathi, A.; Hariharan, Y.; Janaki, J.; Sankara Sastry, V.; Radhakrishnan, T. S. Solid State Commun. 1992, 84, 823-826. http://dx.doi.org/10.1016/0038-1098(92)90098-T

22. Lu, W.; Ruan, G.; Genorio, B.; Zhu, Y.; Novosel, B.; Peng, Z.; Tour, J. M. ACS Nano 2013, 7, 2669-2675. http://dx.doi.org/10.1021/nn400054t

23. Dresselhaus, M. S.; Jorio, a.; Saito, R. Annu. Rev. Condens. Matter Phys. 2010, 1, 89-108.

http://dx.doi.org/10.1146/annurev-conmatphys-070909-103919

24. Seger, L.; Wen, L.-Q.; Schlenoff, J. B. J. Electrochem. Soc. 1991, 138, 81-82. http://dx.doi.org/10.1149/1.2085516

25. Zhang, R.; Mizuno, F.; Ling, C. Chem. Commun. 2014, 51, 1108-1111.

http://dx.doi.org/10.1039/C4CC08139K

\section{Povzetek}

Opisana je sinteza s fulereni- $\mathrm{C}_{60}$ funkcionaliziranih grafenski nanotrakov, ki so bili pripravljeni iz komercialno dostopnih večstenskih ogljikovih nanocevk po in situ postopku. Fizikalne lastnosti sintetiziranega materiala so bile analizirane z elektronsko vrstično mikroskopijo, presevno elektronsko mikroskopijo, analizo sproščenega plina in ramansko spektroskopijo. Lastnosti funkcionaliziranega materiala so bile nato primerjane z nefunkcionaliziranim. Oba materiala, tako funkcionaliziran, kot nefunkcionaliziran sta bila nato ovrednotena tudi elektrokemijsko. Določena je bila redoks ativnost in kapaciteta obeh v litij-ionskih baterijah. Primerjava obeh materialov je pokazala izboljšano kapaciteto funkcionaliziranega materiala pri nizkih tokovnih gostotah. 